\title{
ORBITAL MULTILOBULAR OSTEOCHONDROSARCOMA IN A DOG
}

\author{
OSTEOCONDROSSARCOMA MULTILOBULAR EM ÓRBITA DE CÃO
}

\author{
Ana Cláudia Santos RAPOSO; Alessandra ESTRELA-LIMA² ; Francisco de Assis DÓREA \\ NETO$^{2}$; Arianne Pontes ORIÁ ${ }^{2}$ \\ 1. PhD student, School of Veterinary Medicine and Zootechny, Federal University of Bahia, UFBA, Salvador, BA, Brazil; 2. PhD, \\ Professor in School of Veterinary Medicine and Zootechny - UFBA, Salvador, Brazil. arianneoria@ufba.br.
}

\begin{abstract}
Retrobulbar tumors may arise from any orbital tissue. Some are primary and others may extend from adjacent structures or derived from metastases. Multilobular osteochondrosarcomas are regarded as slowly growing and potentially malignant neoplasms in dogs. This tumor is of rare occurrence on retrobulbar region. This paper aims to report a rare case of female dog, Shih Tzu, spayed, five-year-old, that was referred to the Hospital of Veterinary Medicine, Federal University of Bahia, Brazil, with an increased volume in the orbital space, after enucleation for exophthalmia of unknown etiology. This animal was evaluated clinic and the diagnosis image (radiography and computed tomography) demonstrated a large formation of bone predominantly in the region of the right orbit and zygomatic arch, with invasion and destruction of adjacent bones. Due to her poor quality of life, the dog was submitted to euthanasia and after necropsy. On gross examination, an encapsulated nodular mass with an irregular surface, measuring 5.6 x 4.6 x $3.9 \mathrm{~cm}$, was located in the right lateral skull, occupying the orbit with displacement of the zygomatic arch. The tumor was identified by histopathology as a malignant mesenchymal neoplasm, multilobular osteochondrosarcoma. Thus, differential diagnoses for exophthalmos should include cancers, including the multilobular osteocondrossarcoma.
\end{abstract}

KEYWORDS: Tumors. Eye. Retrobulbar. Canine.

\section{INTRODUCTION}

Retrobulbar neoplasia may be divided into mesenchymal (including osterosarcoma, fibrosarcoma and multilobular osteochondrosarcoma), epithelial (mostly adenocarcinoma) or miscellaneous (including peripheral nerve sheath tumor, orbital meningioma and mastocytoma) tumors (PEIFFER; SIMONS, 2002).

Multilobular osteochondrosarcomas are regarded as slowly growing, potentially malignant neoplasms, which may affect the canine skull, though occasionally they may be seen in cats (DERNELL et al., 1998; THOMPSON; POOL, 2002; CHUN, 2005). It was reported the occurrence of $11 \%$ of osteocondrossarcoma from bone tumors in dogs (CHUN, 2005). The diagnosis is based on clinical findings, radiography and histopathology (DERNELL et al., 1998; ROSENTHAL, 2004). Depending on the location and extent of the tumor, dogs can be presented for dysphagia and pain when opening the mouth, exophthalmos or neurological signs, due to compression or disruption of function of adjacent structures (ROSENTHAL, 2004).

The only effective treatment is surgical excision; however, complete removal may be difficult or even impossible in some cases (MORRIS; DOBSON, 2007). A prognostic factor is the location of the tumor, as those located in the mandible are more easily excised and the median survival time of these patients may reach 1487 days (CHUN, 2005). This paper describes an unusual case of orbital multilobular osteochondrosarcoma in a dog, with swelling in the orbital region.

\section{CASE REPORT}

A five-year-old, female Shih Tzu, spayed, was referred to the Hospital of Veterinary Medicine, Federal University of Bahia, Salvador, Bahia, Brazil, due to swelling of the right retrobulbar region. The owner reported that one year earlier the right eye was enucleated due to exophthalmos of unknown etiology. Since then, the dog has been suffered from recurrent accumulation of serouspurulent and bloody discharge, drained through a fistula. It has been treated by several drainage procedures combined with systemic antibiotics, antiinflammatories and opioids.

Physical examination was unremarkable except for tachypnea, enlarged submandibular lymph nodes, and a firm mass in the right orbital region. Ophthalmic examination of the left eye was unremarkable except for congested episcleral vessels, a decreased direct pupillary reflex, and increased intraocular pressure $(29 \mathrm{mmHg}$ - Tonopen XL (). Skull radiography showed a soft tissue mass in the right orbit with loss of definition in the ipsilateral zygomatic bone (Figure 1). 


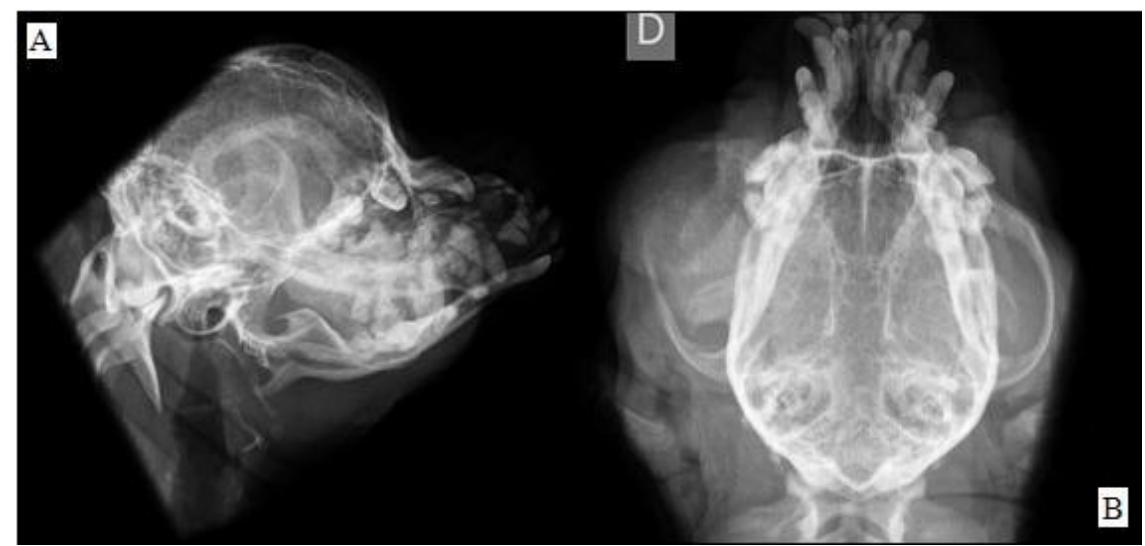

Figure 1. Skull radiographs of a five-year-old female Shih Tzu with multilobular osteochondrosarcoma. (A) lateral view. Note the loss of definition in the zygomatic bone. (B) Ventro-dorsal view. Note the soft tissue mass in the right orbit.

Skull computed tomography (CT) demonstrated a large formation of bone predominantly in the region of the right orbit and zygomatic arch, with invasion and destruction of adjacent bones (Figure 2). Subluxation of the right temporomandibular joint, as well as osteoarthritis and fracture of the right coronoid process, was also demonstrated moderate lymphadenopathy of the left medial retropharyngeal node was observed.

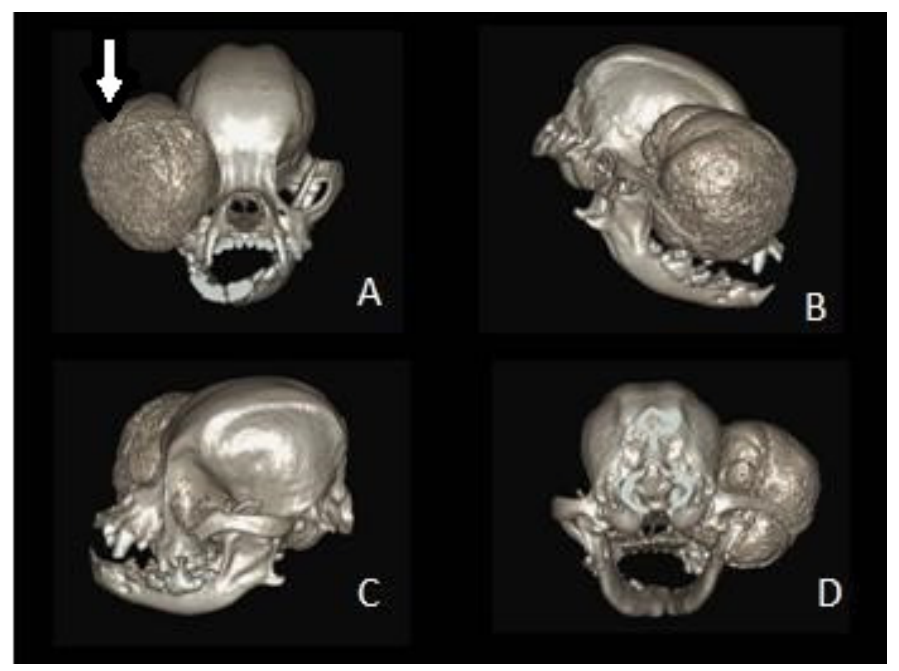

Figure 2. A 3D skull $C T$ reconstruction of a five-year-old, female Shih Tzu with multilobular osteochondrosarcoma. (A) rostral view (B) right lateral (C) left lateral (D) caudal. (Arrow) Note a round bone formation, $5.4 \mathrm{~cm}$ diameter, in the right orbit, with ipsilateral displacement of the zygomatic arch and caudolateral deviation of coronoid process and the right mandibular condyle.

From the imaging results, the size of the tumor, animal clinical evaluation and poor prognosis, the dog was discharged with palliative treatment which included tramadol hydrochloride $3 \mathrm{mg} / \mathrm{kg}$ every $8 \mathrm{~h}$ and carprofen $4.4 \mathrm{mg} / \mathrm{kg}$ every $24 \mathrm{~h}$. After one week, despite medical treatment, the animal returned due to difficulties in swallowing, hypodipsia, restlessness and emesis. Because of the poor quality of life, the dog was indicated to euthanasia and submitted to necropsy, in agreement with the owner. On gross examination of the body (Figure 3) an encapsulated nodular mass with an irregular surface, measuring $5.6 \times 4.6 \times 3.9 \mathrm{~cm}$, was located in the right lateral skull, occupying the orbit with displacement of the zygomatic arch. Local invasion with focal lysis of the parietal, temporal and frontal bones was diagnosed. When the mass was cut, a rough whitish surface, resembling cartilage and bone, was noted. Other pathological findings included mild congestive splenomegaly, liver congestion, mild erosive gastritis, enteritis with focal areas of hemorrhage, discreet nephrosis, moderate renal congestion and pulmonary congestion and edema. 


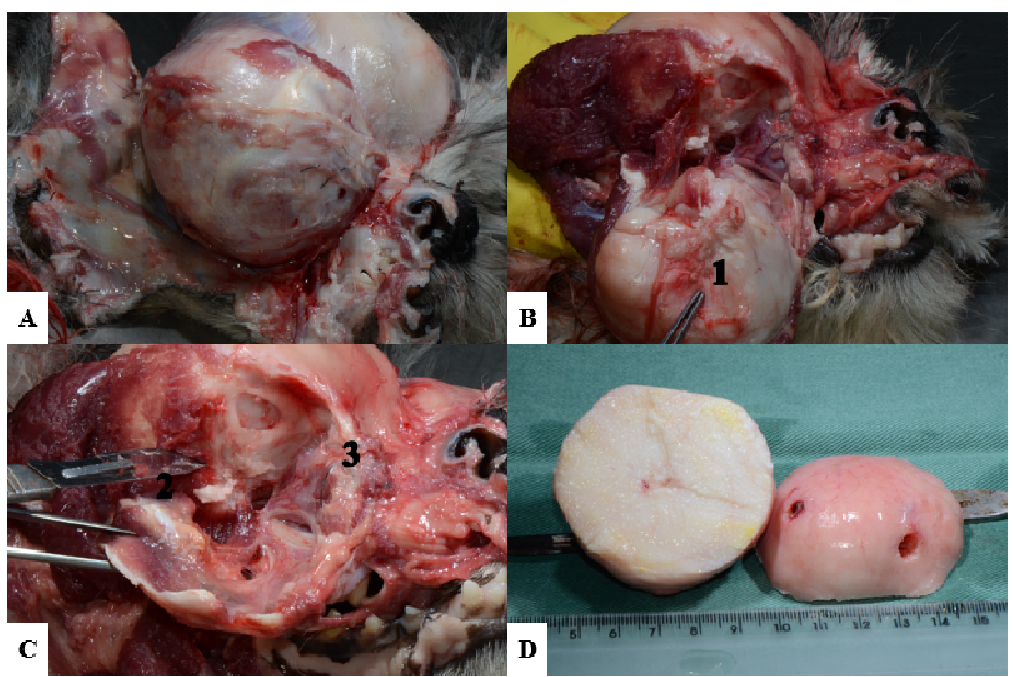

Figure 3. The skull of a 5-year-old, female Shih Tzu with multilobular osteochondrosarcoma. (A/B) A large mass occupying the right orbit and lateral skull (number 1). (C) After the mass removal, temporal and frontal bones (number 2) were seen and invasion with focal lysis of the parietal and compression of the zygomatic arch (number 3). (D) The cut surface of the mass is rough and white, resembling cartilage and bone.

Histopathology of the mass (Figure 4) revealed multiple concentric islands of pleomorphic chondrocytes, atypical osteoblasts and osteocytes surrounded by abundant osteoid matrix. Moderate amount of stroma, a low mitotic rate and areas of necrosis were also observed. The diagnosis was a malignant mesenchymal neoplasm. The conclusion diagnosis was orbital multilobular osteochondrosarcoma.

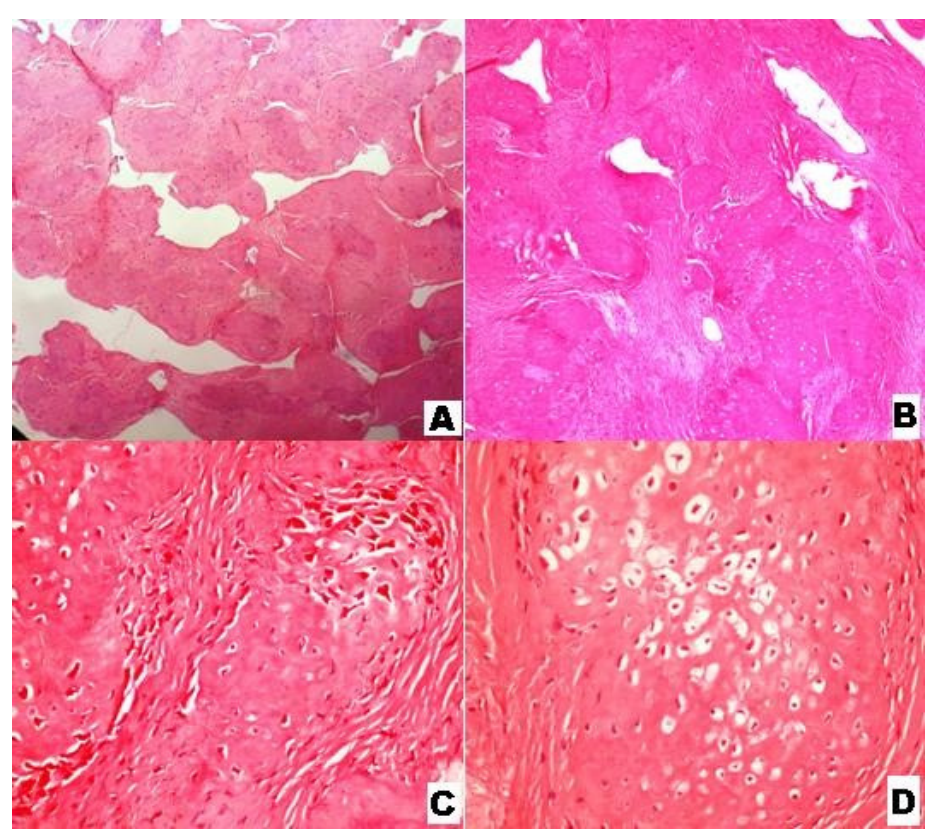

Figure 4. Histopathology of an orbital mass from a five-year-old, female Shih Tzu with multilobular osteochondrosarcoma. (A/B) multiple concentric islands of neoplastic mesenchymal cells sustained by moderate conjunctival stroma. H\&E, 40x. (C) Atypical osteoblasts and osteocytes surrounded by osteoid matrix. H\&E, 100x. (D) Pleomorphic chondrocytes surrounded by cartilage matrix. H\&E, 100x. 


\section{DISCUSSION}

Multilobular bone tumors affect middleaged and elderly dogs of medium and large-size breeds, with no predilection for specific breeds or gender (WITHROW et al., 2007). The tumors usually occur in the skull, are characterized by slow progression, and are potentially malignant (DERNELL et al., 1998; THOMPSON; POOL, 2002; CHUN, 2005). The dog described in this case report was five years old, and of a small breed, which differs from previous reports, relative tumor localization (DIAMOND et al., 1980). However, its tumor had the same predilection to the flat bones of the skull which has been reported by other authors (STRAW et al., 1989)

In a survey of 16 cases of multilobular osteochondrosarcoma in the mandible, maxilla and skull, clinical signs were related to compression of adjacent structures (STRAW et al., 1989). The authors report that $50 \%$ of dogs with lesions involving the skull had neurological signs, $44 \%$ had a stiff dough and stuck as the only sign and additional signs included buphthalmos and pain when opening the jaw due to involvement of the jaw (STRAW et al., 1989). In a study by DERNELL et al. (1998) of 39 dogs with multilobular osteochondrosarcoma, clinical signs were diverse and included the presence of a mass firmly adhered (54\%), swelling (10\%), neurological signs (5\%), ocular signs $(2.5 \%)$, dyspnea $(2.5 \%)$, pain $(2.5 \%)$, mass and exophthalmos (10\%), pain, and exophthalmos $(5 \%)$ and mass and pain $(2.5 \%)$. In the present report the clinical manifestations were exophthalmos and pain during chewing and when opening the mouth due to involvement of the zygomatic, frontal and parietal bones.

Our radiographical findings were an increase of soft tissue in the orbital region with loss of bone definition in the right zygomatic arch. This is in contrast to a report that describes this type of neoplasia as having well-defined borders, granular appearance and speckled mineralized nodular opacities (BRANDÃO et al., 2009).

Anatomical features, fractures and deformities of the skull can be visualized using 3D reconstruction techniques

(HATHCOCK;

NEWTON, 2000). While our radiography suggested the presence of mass, CT was essential to identify, locate and measure the impairment caused by tumor.

In our patient the prognosis was very poor due to the location of the mass, and fracture and involvement of adjacent bones associated with pain, anorexia and apathy.

Cytology may support the diagnosis of bone sarcomas. However, neoplastic osteoblasts and chondroblasts have many features in common, and therefore histopathology is essential to issue a conclusive diagnosis in these cases (THOMPSON; POOL, 2002). The architecture of multilobular osteochondrosarcoma is unique, therefore, when the multilobular image cannot be well-defined, or when there is a predominance of one element over another, with areas of hemorrhage, necrosis and mitotic activity, the diagnosis is suggested (DIAMOND et al., 1980). Upon histopathology it was possible to conclude the diagnosis when we observed at macro and microscopic examinations, characteristics reported previously by other authors in cases of multilobular osteochondrosarcoma (LOSCO et al., 1984; THOMPSON; POOL, 2002).

Surgical removal is often difficult because of the location of these tumors and margins, but it is the indicated procedure (THOMPSON; POOL, 2002; LEONARDI et al., 2014). Others possibilities as early remove were not elucidated due to tumor aggressiveness (LEONARDI et al., 2014).

\section{CONCLUSION}

In the presence of exophthalmos, tumors should be included in the diagnosis, since the early detection combined with excision of the mass can greatly contribute to a more favorable prognosis. Thus, this case report described a differential diagnosis for tumor in orbital space.

\section{ACKNOWLEDGEMENTS}

The authors acknowledge the veterinaries Kátia Requião, Miucha de Almeida Furtado, Rodrigo Lima Carneiro and Natalie Borges.

RESUMO: Tumores retrobulbares podem originar-se de qualquer tecido orbital. Alguns são primários e outros podem estender-se a partir de estruturas adjacentes ou derivados de metástases. O osteocondrosarcoma multilobular é um tumor considerado de crescimento lento, potencialmente maligno e sua ocorrência é considerada rara em região orbital. Este trabalho objetiva descrever um caso de uma cadela, Shih Tzu, castrada, com cinco anos, atendida no Hospital de Medicina Veterinária da Universidade Federal da Bahia, Brasil, com apresentação de aumento de volume no espaço orbital, após enucleação devido a exoftalmia de etiologia desconhecida. O animal foi avaliado clinicamente e por exames de imagem (radiografia e tomografia computadorizada), os quais demonstraram uma grande formação óssea 
predominantemente na região da órbita direita e arco zigomático, com invasão e destruição dos ossos adjacentes. Devido às más condições de sobrevida apresentada pelo animal, foi indicado o procedimento de eutanásia e por fim, submetido à necropsia. No exame macroscópico, uma massa nodular encapsulada de superfície irregular, medindo 5,6 x 4,6 x 3,9 centímetros, foi localizada no crânio lateral direito, ocupando a órbita com deslocamento do arco zigomático. O tumor foi identificado por exame histopatológico como neoplasia mesenquimal maligna, osteocondrossarcoma multilobular. Desta forma, diagnósticos diferenciais para exoftalmia devem incluir neoplasias, dentre elas o osteocondrossarcoma multilobular.

PALAVRAS-CHAVE: Tumor. Olho. Retrobulbar. Canino.

\section{REFERENCES}

BRANDÃO, C. V. S.; SERENO, M. G.; RANZANI, J. J. T.; VULCANO, L. C.; ANGÉLICO, G. T.; VIEIRA, N. M. G.; DONATTI, C. Estrabismo divergente e exoftalmia secundária a osteossarcoma condroblástico no cão. Relato de caso. Vet. Zootec., Botucatu, v. 16, p. 303-308, 2009.

CHUN, R. Common malignant musculoskeletal neoplasms of dogs and cats. Vet. Clin. Small Anim., New York, v. 35, p. 1155-1167, 2005. http://dx.doi.org/10.1016/j.cvsm.2005.05.004

DERNELL, W. S.; STRAW, R. C.; COOPER, M. F.; POWERS, B. E.; LARUE, S. M.; WITHROW S. J. Multilobular osteochondrosarcoma in 39 dogs: 1979-1993. J. Am. Anim. Hosp. Ass., Colorado, v. 34, p.11-18, 1998. http://dx.doi.org/10.5326/15473317-34-1-11

DIAMOND, S. S.; RAFLO, C. P.; ANDERSON, M. P. Multilobular osteosarcoma in the dog. Vet. Pathol., San Diego v. 17, p. 759-763, 1980. http://dx.doi.org/10.1177/030098588001700611

HATHCOCK, J. T.; NEWTON, J. C. Computed tomographic characteristics of a multilobular tumor of bone involving the cranium in 7 dogs and zygomatic arch in 2 dogs. Vet. Radiol. Ultras., Oxford, v. 41, p. 214-217, 2000. http://dx.doi.org/10.1111/j.1740-8261.2000.tb01480.x

LOSCO, P. E.; DITERS, R. W.; WALSH, K. M. Canine multilobular osteosarcoma of the skull with metastasis. J. Comp. Pathol., London, v. 94, p. 621-624, 1984. http://dx.doi.org/10.1016/0021-9975(84)900689

LEONARDI, L.; CARRANO, A.; STOPPINI, L.; FLORIS, M. Multilobular tumor of the zygomatic bone in a dog. Open Vet. J., v. 4, p. 9-11, 2014.

MORRIS, J.; DOBSON, J. Oncologia em Pequenos Animais. São Paulo: Roca, 2007.

PEIFFER Jr., R. L.; SIMONS, K. B. Orbital tumors. In: . Ocular tumors in animals and humans. Ames: Iowa State Press, 2002. p. 3-4.

ROSENTHAL, R. C. Segredos em oncologia veterinária. Porto Alegre: Artmed, 2004, p. 99-199.

STRAW, R. C.; LECOUTEUR, R. A.; POWERS, B. E.; WITHROW, S. J. Multilobular osteochondrosarcoma of the canine skull: 16 cases (1978-1988). J. Am. Vet. Med. Assoc., Ithaca, v. 195, p. 1764-1769, 1989.

THOMPSON, K. G.; POOL, R. R. Tumors of bones. In: MEUTEN, D. J. Tumors in domestic animals. 4.ed. Ames: Iowa State Press, 2002, p. 245-318. http://dx.doi.org/10.1002/9780470376928.ch5

WITHROW, S. J.; VAIL, D. M.; PAGE, R. Withrow \& MacEwen's small animal clinical oncology. Saint Louis: SAUNDERS, 2007. 